NIILO IKOLA

\title{
Mikael Agricolan suomentamat Raamatun kohdat ja niiden osuus koko Raamatusta
}

Mikael Agricolan työtä Raamatun kääntämiseksi suomen kielelle on tietääksseni julkisuudessa ensimmäisenä käsitellyt H. G. PorThan kirjoituksessaan "Kortt Historia om Finnska BibelÖfwersättningen", joka ilmestyi kirjoitussarjana v. 1778 lehdessä "Tidningar Utgifne Af et Sällskap i Åbo". Agricolan kirjoista mainitaan lehden numeroissa 12 ja 13 Uusi testamentti ja Psalttari sekä 1551 ilmestynyt Weisut ia Ennustoxet; viimeksi mainitun nimeä PoRThan ei mainitse, mutta sen sijaan hän tekee selkoa, mistä Raamatun kirjoista sen sisällys on koottu. Samoin esitetään myös 1552 ilmestynyt kirja, joka sisälsi kolme jäljellä olevaa pientä profeettaa, siis "Ne Prophetat. Haggai. SacharJa. Maleachi.". Mainituiksi tulevat siis vain ne Agricolan kirjat, jotka sisälsivät suoranaisesti Raamatun kirjain käännöstä.

Arviointia Agricolan suomennostyön laajuudesta Porthanin historiikissa ei ole. Useassa myöhemmässä julkaisussa tietenkin puhutaan Agricolan suorittamasta Raamatun käännöksestä, mutta en ole huomannut, että niissä olisi käsitelty kysymystä siitä, kuinka suuren osan Raamatusta Agricola on kääntänyt, ennen kuin vasta tämän vuosisadan puolella. Vuonna 1908 ARTHUR HJELT julkaisi Varsinaissuomalaisen Osakunnan albumissa Lännetär (Uusi jakso I s. 169-) kirjoituksen "Kuinka paljon on Agricola Vanhaa Testamenttia suomentanut tai suomeksi toimittanut?" Kirjoituksessa luetellaan kaikki Agricolan kääntämät Vanhan testamentin kohdat apokryfikirjoja lukuun ottamatta. Tutkielman lopussa HJELT esittää tuloksena: "Siis on Agricola suomentanut tai suomeksi toimittanut enemmän kuin puolet Vanhan Testamentin kanoonisista kirjoista." 
Tämä tulos perustui kuitenkin erehdykseen. Vanhan testamentin sivuja laskettaessa ei ollut otettu huomioon, että laskelmien perustana käytetyssä Raamatussa alkoi Jobin kirjan alusta uusi sivunumerointi, ja vain tämä lukusarja oli laskettu koko Vanhan testamentin sivumääräksi. HJELT korjasi tämän avustajansa tekemän virheen jo samana vuonna Suomen Kirkkohistoriallisen Seuran kokouksessa pitämässään esitelmässä "Mikael Agricola Uuden Testamentin kääntäjänä" (SKHS pöytäk. VIII 1908, s. 42) seuraavasti: "Agricola on suomentanut tai suomeksi toimittanut V.T:in kanoonisista kirjoista 22,7 \% eli siis ei täyttä neljättä osaa." (Oman Maan V nidoksessa 1910 s. 376.) HJELт esittää samansisältöisen tiedon: "Agricola kääntänyt Vanhan testamentin kanoonisista kirjoista miltei neljännen osan $(22,7 \%)$."

Kysymystä Agricolan osuudesta Raamatun suomentamisessa ovat myös useat muut tutkijat käsitelleet. Niinpä suuresti ansioitunut Agricolan kirjallisen tuotannon tutkija JAAKKo GuMmerus sanoo teoksessaan Mikael Agricola 1908 s. 49 hänen "suomentaneen tai suomeksi toimittaneen lähes neljännen osan Vanhan Testamentin kanonisista kirjoista ja lisäksi pieniä kappaleita apokryfakirjoista". Tästä asiasta on maininta myös Gưmeruksen teoksessa Mikael Agricolan Rukouskirja ja sen lähteet (I 1941, s. 3): "Uutta Testamenttia seuraavat 1551-1552 vanhan Testamentin eri osien suomennokset ('Dauidin Psaltari', 'Weisut ia Ennustoxet' ja 'Ne Prophetat Haggaj, SacharJa, Maleachi') sisältävät yhteensä lähes neljännen osan Vanhan Testamentin kanonisista kirjoista ja lisäksi pieniä kappaleita Apokryfakirjoista."

Tämä sanonta ei kuitenkaan ole aivan tarkka, sillä ilmoitettu tulos edellyttää, että lukuun otetaan myös Rukouskirja, jota tässä ei kuitenkaan mainita.

Uuden testamentin sekä lähes neljänneksen Vanhaa testamenttia sanoo myös A. F. Puukko Agricolan kääntäneen. (Suomalainen Raamattumme 1946 s. 7.)

MARTti RAPola, vanhan kirjakielemme etevä tuntija, on parissa julkaisussaan antanut tietoja myös Agricolan osuudesta koko Raamatun suomentamisessa. Teoksessaan Vanha kirjasuomi (1945 s. 24) hän lausuu: "Uuden Testamentin lisäksi Mikael Agricola suomensi ja julkaisi Vanhan Testamentin kirjoja ja erillisiä kappaleita niin paljon, että hänen on laskettu kääntäneen kielellemme noin kaksi 
viidennestä koko Raamatusta." Tämä kohta on aivan samoin teoksen 1962 ilmestyneessä uudessa painoksesssa s. 41. Saman tutkijan 1957 julkaisemassa teoksessa Lehtiä Mikael Agricolan raamatusta (s. 10) on tästä asiasta erilainen tiedonanto: "Kun Agricola v. 1557 kuoli, hän oli ennättänyt julkaista n. kaksi kolmannesta koko Raamatusta: Uuden testamentin lisäksi neljänneksen Vanhaa testamenttia."

Agricolan osuutta Raamatun suomeksi kääntämisessä on myös tämän kirjoittaja käsitellyt. Kirjoitelmassani "Ensimmäisen suomalaisen raamatun historiaa" (Turun Historiallisen Yhdistyksen julkaisuja II 1927 s. 38) olen HJELTin tutkimukseen nojautuen lausunut, että Agricola on kääntänyt suomeksi koko Uuden testamentin ja "Vanhan Testamentin kanonisista kirjoista lähes neljännen osan eli tarkemmin sanoen $22,7 \%$."

Tähän kysymykseen jouduin kajoamaan myös Oman Maan uuteen laitokseen kirjoittamassani artikkelissa "Suomalainen Raamattu". Mainitsin siinä samoin Vanhan testamentin kanonisista kirjoista tulleen käännetyksi 22,7 \%. Käyttäen tätä prosenttilukua laskelmieni perusteena Vanhan testamentin osalta sain tulokseksi, että koko Raamatusta tuli Agricolan suomentamana julkaistuksi noin $42 \%$ (Oma Maa 71960 s. 52).

Edellä mainitut tutkijat näyttävät siis yhtäpitävästi olevan sillä kannalla, että Agricola käänsi Vanhasta testamentista lähes neljännen osan. Tämä perustuu nähtävästi edellä mainittuun HJELTin tutkimukseen. Muutamat heistä eivät kuitenkaan ole huomanneet tai ainakaan huomauttaneet, että HJELT sanoessaan Agricolan kääntäneen "miltei neljännen osan (22,7 \%)" puhuu nimenomaan Vanhan testamentin kanonisista kirjoista. Agricolan osuuden määritelmä muuttuu koko lailla toiseksi, jos otetaan huomioon koko Vanha testamentti.

Edellä esitetyt Agricolan osuutta koko Raamatun kääntämisessä koskevat tiedot eivät kuitenkaan kaikki ole yhdenmukaisia. Lisäksi näyttää olevan moniaita muita seikkoja, joiden takia on aihetta ottaa tämä kysymys koko laajuudessaan vielä tarkasteltavaksi.

Tutkittaessa kysymystä, mitkä Raamatun kohdat Agricola on suomentanut ja kuinka suuren osan ne muodostavat Vanhasta ja Uudesta testamentista sekä myös koko Raamatusta, tulee lähinnä suoritettavaksi kaksi tehtävää. Ensinnäkin on Agricolan teoksista. haettava kaikki suoraan Raamatusta otetut kohdat ja laadittava 
niistä luettelo, jossa ne on asetettu siihen järjestykseen, missä ne Raamatun eri kirjoissa esiintyvät. Seuraavana tehtävänä on mitata luetteloon merkityt Raamatun kohdat. Tällöin on otettava pohjaksi jokin kokoraamatun painos, johon on ikään kuin projisioitava Agricolan kääntämät kohdat, ja laskettava, kuinka suuren osan tästä mittauksen pohjana olevasta Raamatusta Agricolalla olevat suomennetut kohdat muodostavat.

Tietääkseni ensimmäisen Agricolan kääntämien Raamatun paikkain luetteloinnin on suorittanut kirkkoherra J. A. Cederberg teoksessaan "Suomalaisen Raamatun Historia Gezeliuksen aikoihin saakka", joka ilmestyi synodaaliväitöskirjana vuonna 1885. Siinä hän sivuilla 40-41 luettelee Agricolan Rukouskirjaan otetut Raamatun kappaleet. ${ }^{1}$ Sivulla 62 on lueteltu Agricolan Weisut ia Ennustoxet -teokseen sisältyvät Vanhan testamentin kohdat ylimalkaisesti. Tämän luettelon hän sanoo tehneensä PoRTHavin mukaan "Åbo Tidningar" lehdessä 1778 n:ossa 13 julkaistun kirjoituksen perusteella. Cederberg ei ole voinutkaan tätä teosta itse tutkia, koska "kirjasta ei ole säilynyit yhtään kappaletta meidän ajallemme", kuten hän sanoo. Nähtävästi tätä kirjaa ei vielä 1885 ollut Helsingin Yliopiston kirjastossa, vaan se on saatu sinne myöhemmin.

Sivulla 66 on tietoja Ne Prophetat. Haggai. SacharJa. Maleachi. -teoksessa olevista suomennetuista kappaleista. CEDERBERgin tutkimuksessa olevista Agricolan suomentamia Raamatun kappaleita koskevista tiedoista muodostuva luettelo on kuitenkin sangen vaillinainen, ja siinä on joukko virheitä.

Edellä on jo mainittu ArThuR HJELTin tutkimus 'Kuinka paljon on Agricola Vanhaa Testamenttia suomentanut tai suomeksi toimittanut?" Siinä on ensin tehty selkoa siitä, mitä Vanhan testamentin kohtia sisältyy suomennettuina Agricolan eri kirjoihin, ja sen jälkeen on yhtenäinen luettelo Vanhasta testamentista käännetyistä kohdista. Tähän suurta vaivaa ja huolellisuutta vaatineeseen luetteloon on kuitenkin päässyt pujahtamaan muutamia virheitä. Täytynee myös pitää puutteellisuutena sitä, ettei ole mainittu, millä

\footnotetext{
1 Selvityksettä jää, mistä CeDERBerg on saanut nämä tiedot, sillä s. 39 alav. 1 hän lausuu: "emme itse ole päässeet tilaisuuteen nähdä rukouskirjaa." Tlmeisesti hänellä on täytynyt olla joku avustaja, jota hän ei kuitenkaan mainitse.
} 
sivulla Agricolan kirjoissa luettelossa mainittu Raamatun kohta tavataan.

Agricolan kääntämiä Raamatun kohtia hänen kirjoistaan haettaessa on suuri vaara karahtaa salakarille, eikä HJELTkään ole tästä vaarasta joka kohdassa välttynyt. Asian tekee erikoisen vaikeaksi ja suuritöiseksi se, että Agricolan raamatunkäännöstä sisältävissä teoksissa lukujen teksti Psalttaria lukuunottamatta on usein sangen pitkinä kappaleina ilman jakoa eri jakeisiin, ja jakeiden numerointi puuttuu kokonaan, myös Psalttarista. Weisut ia Ennustoxet -teoksessa on kyllä jaejako, mutta se ei vastaa nykyisen Raamattumme jakoa. Jotta voisi todeta, mitä Agricola on kustakin luvusta kääntänyt, on jae jakeelta verrattava Agricolan tekstiä johonkin Raamattuun, jossa on jaejako ja jakeiden numerointi. Tämä vaatii suurta ja tarkkaa työtä, sillä Agricola on useissa tapauksissa menetellyt siten, että hän on kesken kääntämäänsä lukua tai luvun osaa jättänyt muutamia jakeita välistä pois tai ottanut jostakin jakeesta vain pienen osan alusta, keskeltä tai lopusta. On siis tarkastettava jokainen jae. Tällaisessa työssä voi helposti jokin virhekin päästä pujahtamaan. Mainittakoon jokunen esimerkki. Suomennettujen kohtien luettelossa on HJELTillä merkintä Esr. 9, 6-15. Tämä Esran 9. luku on Rukouskirjan näköispainoksessa I s. 127-128. Siinä on kuitenkin vain jakeet $6,7,10,11$ a, 13-15. Jakeet 8, 9, suurin osa jaetta 11 ja jae 12 puuttuvat eli siis lähes kolmannes HJELTin mainitsemasta määrästä. Jesajasta HJELт ilmoittaa käännetyksi mm. luvun 43. Tästä luvusta on Rukouskirjassa I s. 335-336 jakeet 24 b, 25-27 sekä kirjassa W.eisut ia Ennustoxet III s. 488490 jakeet $1-7,10-13,21-28$. Jakeet $8,9,14-20$ eli siis yhdeksän jaetta 28 :sta puuttuu. Joskus on tässä luettelossa myös päinvastainen virhe : ei ole merkitty kaikkia jakeita, jotka asianomaisessa kohdassa tavataan esim. Siirak Käsikirja III s. 49 10:12 b-13. Oikea merkintä olisi: Siirak 10: 9-13; edelleen Lisäyksiä Esterin kirjaan Rk. I s. 167 HJELtillä 2: 4-10, pitäisi olla 2: 4-19, uusi käännös 4: $3 \mathrm{~b}-19$. On siis 16 jakeesta otettu Iuetteloon vain seitsemän.

Edellä mainittuun GummerukseN tutkimukseen "Mikael Agricolan Rukouskirja ja sen lähteet I" sisältyy viitteinä merkintöjä niistä Raamatun kohdista, jotka ovat Rukouskirjassa I sivuilla 121 - 344. Näistä viitteistä ei kuitenkaan muodostu varsinaista yhte- 
näistä luetteloa, sillä ne ovat hajallaan siinä järjestyksessä, kuin asianomaiset Raamatun kohdat esiintyvät Rukouskirjassa. Poikkeuksen muodostavat Rukouskirjaan otetut 40 psalmia, jotka Gummerus on käsitellyt numerojärjestyksessä, vaikka ne Rukouskirjassa eivät olekaan tässä järjestyksessä, vaan hajallaan muiden rukousten joukossa.

GummERuKsen erikoiseksi ansioksi on luettava, että hän on edellä mainitussa tutkimuksessaan ensimmäisenä antanut tarkkoja tietoja Agricolan suomentamien Uuden testamentin kohtien esiintymisestä muissa Agricolan kirjoissa, nim. Rukouskirjassa. Gummerus ei kuitenkaan mainitse kaikkia tähän kirjaan otettuja Uuden testamentin kohtia, vaan hän on rajoittunut vain kirjan jälkiosaan, joka alkaa sivulta 89 (ks. Niilo Ilkola Virittäjä 1950 s. 13). Kirjan alkuosassa latinankielisen osaston jälkeen, ennen Rukouskirjan esipuhetta, on sivuilla 81-88 kohtia Matteuksen, Markuksen, Luukkaan ja Johanneksen evankeliumeista sekä s. 101 Hebrealaiskirjeestä, joita ei ole otettu huomioon. Muihin Agricolan kirjoihin sisältyviä Raamatun kohtia hän ei luettele. Muutamia virheitä, jotka etupäässä lienevät kirjaa painettaessa syntyneitä, on Raamatun paikkojen merkintöihin tullut.

A. F. Puukon "Suomalainen Raamattumme" teoksen lopussa oleva noottiosasto sisältää myös tietoja Agricolan kääntämistä Vanhan testamentin kohdista. Luettelo on osittain ylimalkainen. Tarkimmin on ilmoitettu kirjaan Weisut ia Ennustoxet sisältyvät Raamatun kappaleet. Rukouskirjasta on vain erinäisiä yleispiirteisiä tietoja, ja lopuksi viitataan Gummeruksen edellä mainittuun teokseen. Muutamia epätarkkuuksia PuUkoskin merkintöihin on päässyt.

Edellä mainitut tutkijat ovat sangen vähän kiinnittäneet huomiota Agricolan 1549 ilmestyneeseen teokseen "Se meiden HERRAN Jesusen Christusen Pina, ylesnousemus ia taiuaisen Astumus, nijste Neliest Euangelisterist coghottu". (Agricolan teosten näköispainos III s. 145-195.) CEDERBERg ainoastaan mainitsee tämän teoksen (mt. s. 57); samoin Gummerus (mt. s. 44). HJELTin kirjoituksen aiheeseen Piina ei kuulunutkaan, sillä hän käsitteli yksinomaan Vanhan testamentin kokoonpanoa. PuUkko sanoo vain, että Piinaan "on otettu evankeliumitekstien yhdistelmiä" ja Johanneksen evankeliumin luvut 14-17 (mt. s. 422 , nootti 21 ).

Kun tässä kirjoitelmassa on pyritty ottamaan huomioon kaikki, 
mitä Agricola on julkaisemansa Uuden testamentin ohella muihin kirjoihinsa ottanut Uudesta testamentista, niin on syytä käsitellä myös Piinan kokoonpanoa.

Piinan kirjoittamista suunnitellessaan Agricola nähtävästi on halunnut luoda kokonaisesityksen, joka sisältäisi kaiken, mitä evankeliumeissa on kerrottu Jeesuksen toiminnasta ja siihen liittyvistä tapahtumista viimeisinä aikoina aina taivaaseen astumiseen asti. Suunnitelmaa toteuttaessaan hän on menetellyt siten, että hän on ottanut eri evankeliumeista eripituisia jaejaksoja, yksinäisiä jakeita, jakeen osia, vieläpä väliin yksinäisiä sanojakin ja sovittanut ne yhtenäiseksi esitykseksi. Tästä on seurauksena, että teksti koostuu väliin aivan pienistä eri paikoista otetuista palasista. Niinpä Piinan ensimmäinen lehti (s. 147-148) on pantu kokoon 22 :sta Matteuksen, Markuksen, Luukkaan ja Johanneksen evankeliumeista otetusta kohdasta. Näillä vajaalla kahdella sivulla on kysymykseen tulevasta jakeesta useimmiten otettu vain pieni pala alusta, keskeltä tai lopusta. Vain kolmessa tapauksessa on kaksi tai useampia saman evankeliumin jakeita peräkkäin. Muutamin paikoin näyttää siltä, että Agricola on omasta muististaan ottanut jonkin kohdan. Näin lienee asianlaita esim. Piinan sivulla 189, jossa puolen sivun pituisessa kappaleessa on seitsemän eri evankeliumeista otetun palasen joukossa jae 1 Kor. $15: 6$.

Agricolan Piinan kokoonpanossa noudattamasta menettelytavasta johtuu, että sitä tutkittaessa vaaditaan paljon vaikeata ja aikaa viepää työtä, kun on yritettävä selvittää, mistä Raamatun kirjasta ja paikasta mikin kohta on peräisin. Tuntuu kuin liikkuisi vajottavassa tiheikössä, jossa tukevan jalansijan lopulta löydettyään saa taas pitkään tunnustella, mihin voisi seuraavalla askeleella jalkansa sijoittaa.

Kun tämän kirjoitelman tarkoituksena on ensi sijassa osoittaa, kuinka paljon ja mitkä kohdat Raamatusta Agricola on kääntänyt, niin yksinomaan tämän tehtävän kannalta ei Piinan kaikkien yksityiskohtien alkuperän selvittämiseen ulottuvalla tutkimisella ole merkitystä, koska Agricolan suomentamaan Uuteen testamenttiin jo sisältyy myös Piinan puhtaasti raamatullinen aines. Tarkkaa selvitystä vaille jää sen sijaan tässä yhteydessä kysymys siitä, kuinka paljon Piinaan sisältyy Uuden testamentin tekstiä, ja myös, kuinka suuri osa Uudesta testamentista on julkaistuna Agricolan muissa 
kirjoissa Piina mukaan luettuna. Nämä muutamat viittaukset siihen, miten Agricola on Piinan pannut kokoon, luonevat kuitenkin jonkin verran valaisua Agricolan tässä työssä noudattamaan suunnitelmaan ja menettelytapaan. ${ }^{2}$ Agricolan teoksiin sisältyvien Raamatun kohtien luettelo ei ole Piinan osalta täydellinen, mutta perinpohjaisemman selvityksen tekemiseen tämän teoksen kokoonpanosta ei tässä yhteydessä ollut mahdollisuuksia.

Agricolan osuutta Raamatun suomentamisessa käsitelleistä tutkijoista ARThur HJELT on siis ensimmäisenä laatinut täydellisen luettelon hänen kääntämistään kohdista, mutta kuitenkin vain Vanhan testamentin osalta, sillä sehän hänen tutkimuksensa kohteena olikin. Tämän Iuettelon perusteella hän on laskenut, kuinka suuren osan Agricolan kääntämät kohdat muodostavat Vanhasta testamentista. Laskelmiensa pohjana hän on käyttänyt 1845 ilmestynyttä Raamattua. Tämän painoksen valitseminen tähän tarkoitukseen tuskin on ollut paras mahdollinen ratkaisu, sillä useista syistä se käsittääkseni ei hyvin sovi tähän tehtävään. Vuoden 1845 Raamatussa on, kuten yleensä muissakin painoksissa, eri lukujen alussa otsikot, joissa on lyhyitä tietoja lukujen sisällyksestä. Nämä vievät huomattavasti tilaa. Samoin on jakeiden jäljessä hyvin yleisesti viitteitä paralleelipaikkoihin, jotka koskevat samaa asiaa. Näitä viitteitä on muutamissa Raamatun kirjoissa sangen runsaasti, usein pari kolmekin riviä jakeen jäljessä. Edelleen on tässä Raamatussa usein menetelty siten, että raamatunlauseet, joiden merkitystä tahdotaan erikoisesti tähdentää, on painettu lihavilla kirjasimilla. Nämä seikat vaikuttavat kukin osaltaan laajentavasti Raamatun kokoon.

НлЕLт ei ilmoita, miten hän on laskelmia tehdessään näihin kysymyksiin suhtautunut. Olisi kai kylläkin mahdollista, että kaikkien

${ }^{2}$ On tosin väliin tullut mieleen sekin mahdollisuus, että Agricolalla olisi Piinaa kirjoittaessaan ollut esikuvana, ehkä työn pohjanakin jokin vieraskielinen, lähinnä kai saksalainen teos, jonka hän olisi suoraan kääntänyt suomeksi. Tämä kysymys jää tällä kertaa avoimeksi, mutta en kuitenkaan pitäisi mainittua oletusta todennäköisenä, sillä sitä vastaan puhuu se, että Piinan teksti erikoisluontoisesta kokoonpanostaan huolimatta näyttää sentään sangen tarkoin noudattavan Agricolan evankeliumien suomennoksen sanontaa. Näin tuskin olisi asianlaita, jos Piina olisi suoraan käännetty jostakin vieraskielisestä samaan tapaan kokoonpannusta tekstistä. 
edellä mainittujen seikkain vaikutus voitaisiin tarkoilla mittauksilla jossain määrin eliminoida, mutta se vaatisi niin suunnattoman työn, etten voi olettaa sitä suoritetun. $V$ :n 1845 Raamatussa, varsinkaan Uudessa testamentissa ei ole kovinkaan monta sivua, joissa jokin edellä mainituista tekijöistä ei olisi ollut vaikuttamassa painetun tekstin laajuuteen. Kun Vanhasta testamentista käännetty osa joudutaan mittaamaan usein vähäisinä palasina, jolloin edellä mainitut seikat eivät pääse aivan samalla tavoin vaikuttamaan, niin se vaara on lähellä, että Raamatun eri osien keskinäiset laajuussuhteet eivät tule mittausten tuloksissa esille aivan todellisuutta vastaavina.

Harkitessani kysymystä, sopisiko jokin muu Raamattumme paremmin Agricolan suomentamien Raamatun osien laajuuden määrittelyn pohjaksi kuin HJELTin käyttämä, olen päätynyt siihen, että paras mahdollinen on 1685 ilmestynyt raamatunpainoksemme. Tätä Raamattua painettaessa pyrittiin mahdollisimman suureen tilansäästöön, jotta kirja tulisi pienikokoiseksi ja hinnaltaan huokeaksi. Päämäärän saavuttamiseksi on käytetty useita eri keinoja. Lukujen alussa olevat sisällysluettelot ja myös viitteet paralleelipaikkoihin on siirretty sivujen marginaaleihin. Tekstikuvia ei ole ja muitakin varsinaisia koristeita sangen vähän. Pienintälkään tilaa ei ole jätetty käyttämättä. Uudelta sivulta tai palstalta alkavan luvun otsake on ladottu edelliselle sivulle tai palstalle, jos se vain suinkin on saatu siihen mahtumaan, esim. VT s. 112,549 , 895, tai myös samalle riville kuin edellisen luvun viimeiset sanat, esim. UT s. 66, 90, 204, 279. Vieläpä on väliin jonkin uudelta sivulta alkavan Raamatun kirjankin otsake painettu edellisen sivun loppuun, esim. Propheta Jesaia s. 705 (ks. myös s. 703). Mainita ansainnee vielä käyttämäni 1685 :n Raamatun pienenä etuna 1845 :n painokseen verraten, että edellisessä kahteen palstaan jaetun sivun palstat ovat hyvin kapeita, vain $52 \mathrm{~mm}$, mutta jälkimmäisessä huomattavasti leveämpiä, nimittäin $87 \mathrm{~mm}$. Kun jakeen viimeinen rivi ei useinkaan täytä juuri täsmälleen koko palstan leveyttä, niin tällöin syntyy mittauksessa pientä epätarkkuutta, ja virhe on sitä suurempi, mitä leveämpi painopalsta on. Aiheutuisi kuitenkin aivan liian paljon tuskin tarkoitustaan vastaavaa työtä, jos tämäkin seikka pyrittäisiin ottamaan huomioon. Kun lisäksi tilanne sekä Vanhassa että Uudessa testamentissa on tässä suhteessa samanlainen, niin puheena olevan epätarkkuuden vaikutus mittauksien tuloksiin lienee vähäpätöinen. 
Toisen raamatunpainoksemme käyttämistä esillä olevaan tarkoitukseen puoltaa edelleen sekin seikka, että painettaessa Uutta testamenttia, joka valmistui ensin (1683), eri kirjain esipuheet jätettiin kokonaan pois. Vasta Vanhaa testamenttia painettaessa otettiin siihen esipuheet oikeille paikoilleen kirjain alkuun. Uuden testamentin esipuheet painettiin sitten myöhemmin ja liitettiin yhtenä ryhmänä sen alkuun. Uuden testamentin varsinaiseen sivujen numerointiin nuo esipuheet, joita on 22 sivua, eivät ollenkaan sisälly. Jos ne olisi ladottu asianomaisille paikoilleen Uuden testamentin 27 kirjan alkuun, niiden erottaminen mittauksessa olisi saattanut aiheuttaa jonkin verran epämääräisyyttä. Vanhan testamentin osalta on tietenkin esipuheet vähennettāvä̈, jotta saataisiin Raamatun varsinaisen tekstin runko esille.

Edellä esitetyt seikat tekevät 1685 :n Raamatun erikoisen sopivaksi apuvälineeksi Agricolan osuutta Raamatun suomentamisessa määriteltäessä ${ }^{3}$.

Käyttäen tämän Raamatun ohella apuna myös 1938 hyväksyttyä uutta käännöstä ja Agricolan Uutta testamenttia sekä ottaen huomioon edellä mainittujen aikaisempien tutkijain tiedonannot kävin läpi kaikki Agrieolan teokset (näköispainoksina). Merkitsin muistiin kaikki niistä löytämäni Raamatun paikat ja määrittelin, mistä Raamatun kirjasta ja luvusta ne olivat sekä mitä jakeita tai jakeen osia niihin sisältyi. Täten saadut merkinnät muutin Raamatun kirjain ja asianomaisten Raamatun kohtien alkuperäiseen järjestykseen. Näin syntyi seuraava luettelo.

\section{Luettelo Mikael Agricolan suomentamista Raamatun kohdista ${ }^{4}$}

\section{Vanha testamentti}

1 Moos. Me. III s. 131 1, s. 133 2, s. 135 3, s. 1374 , s. 123 22: 1-19, Rk. I s. 312 28:20-22, s. 154 32: 9-12.

\footnotetext{
${ }^{3}$ Mainittakoon lisäksi, että käyttämäni 1685:n Raamatun jälkeen olisivat tämänkaltaisen työn pohjana mielestäni lähinnä saattaneet tulla kysymykseen Suomen Pipliaseuran kustantamina v. 1817 ja 1819 ilmestyneet Raamatut, joissa on myös apokryfikirjat.

${ }_{4}^{4}$ Merkintätapa ja ly henteet:

Raamatun kirjain nimien lyhenteet ovat tavanomaiset.

Agricolan kirjain nimien lyhenteet: Abck. = Abckiria 1543, Käs. = Käsi-
} 
2 Moos. Rk. I s. 185 15: 1 b-19, WE III s. 439 15: 1-19, Proph. III s. 770 19, s. 772 20, Abck. I s. 5 20: 5-17, Rk. I s. 121 32: 11 b-13, s. 122 32: $31 \mathrm{~b}-32$.

3 Moos. Proph. III s. 775 18, Me. III s. 120 19: 1, $10 \mathrm{~b}-18$, Proph. III s. 777 20, Me. III s. 125 26: $3-46$.

4 Moos. Rk. I s. 188 6:24-26, s. 327 10: 35 b, 36, 12:11b-13, s. 122 14: $17-19$, s. $12316: 22 \mathrm{~b}$.

5 Moos. Rk. I s. 328 3: $24-25$, s. 123 9: 26 b—29, Proph. III s. 780 27: 9 -26, s. 782 28, WE III s. 441 31: 30 , Rk. I s. $10832: 1-43$, WE III s. $44132: 1-43$.

Joos. Rk. I s. 155 7: 7-9, s. 328 7: 20 b.

Tuom. Rk. I s. 15610 : 10, 15 b, s. 156 16: 28 b.

1 Sam. Rk. I s. 312 1:11 c, s. 189 2:1-10, WE III s. 447 2:1-10, 17: $34-54$.

2 Sam. Rk. I s. 191 7:18 b-29, s. 329 12:13 c, s. 227 22: 2-51, WE III s. 450 23:1-7 [Lehti VI (= s. 449-450) on niin näköispainoksessa kuin alkuperäisessäkin WE:ssa kahteen kertaan, joten III s. 452 on myös 23: 1-7].

1 Kun. Rk. I s. $3133: 6-9$, s. $6963: 7-9$, s. $1248: 15,23$ b, 25 a, 27$30,46-52,56-61$.

2 Kun. Rk. I s. 329 20: 3 a.

2 Aik. Rk. I s. 157 14: 11, 20: 6-12, WE III s. 453 20: 5-12.

Esra Rk. I s. 127 9: 6-7, 10-11 a, 13-15.

Neh. Rk. I s. 128 1: 5-7, 10-11 a, s. 158 4: $4-5$, s. 130 9: 5 b-38.

Job Rk. I s, 170 1: 20 b-21, 2: 10 c, Käs. III s. 48 19: $25-27$ a.

Dauidin Psaltari III s. 215-435. Psalttarista puuttuu kuitenkin psalmin 44 jae 7 sivujen 272-273 taitekohdasta. Sitä ei ole muissakaan Agricolan kirjoissa.

Ennen Psalttaria ilmestyneessä Rukouskirjassa oli jo suomennettuina 40 psalmia, nim.: Rk. I s. 255 3: 2-loppuun, s. 256 6:2-1., s. 258 7:2-1., s. 195 9, s. 26010 , s. 262 12: 2 -l., s. $26413: 2-$ l., s. 265 17, is. $26720: 2-\mathrm{l}$., s. 26925 , s. 271 31: 2 -1., s. 725 31: 6 , s. 275 32, s. 198 33, s. 201 34: 2-l., s. 27735 , s. 281 38:2-l., s. 284 51: 3-l., s. 287 54:3-l., s. 288 79, s. $29083: 2-$ l., s. 29286 , s. $29488: 2-$ l., s. 29790 , s. 103 95, s. 300 102:

kiria Castesta ... 1549, Me. = Messu eli Herran Echtolinen. 1549, Pi. = Se meiden HERRAN Jesusen Christusen Pina... 1549, Proph. = Ne Prophetat. Haggai. SacharJa. Maleachi. 1552, Ps. = Dauidin Psaltari. 1551, Rk.= Rucouskiria, Bibliasta,... 1544, $\mathrm{WE}=$ Weisut ia Ennustoxet ... 1551.

Roomalaiset numerot I-III ja niiden jäljessä olevat sivunumerot tarkoittavat Agricolan teosten näköispainoksen (Porvoo 1931) osia ja sivuja. Puolilihavalla painetut numerot tarkoittavat Iukuja ja kaksoispisteen jäljessä olevat jakeita.

Jaenumeron jäljessä oleva $a=$ jakeen alusta, mutta ei loppuun asti, $b=$ jakeen jälkiosasta, mutta ei alusta asti. Jos kuitenkin jakeen alusta puuttuu vain pari sisällyksen kannalta vähämerkityksistä sanaa, esim. "ja sanoi", niin tätä ei ole yleensä otettu huomioon. $c=0$ sa jakeen keskeltä. $1=$ psalmin tai luvun loppuun. 
2-1., s. 204103 , s. 206104 , s. 210113 , s. 211 117, s. 303140 : 2-1., s. 305 141, s. 307142 : 2 -1., s. 308143 , s. 212144 , s. 214145 , s. 217146 , s. 218147 , s. 220148 , s. 222149 , s. 223150 .

Sananl. Rk. I s. 314 30: 7-9.

Saarn. Käs. III s. 48 7:2 b-5, 11: 3 b.

Kork.v. Me. III s. 1292.

Jes. WE III s. 456 1, Me. III s. 110 2: $1-5$, WE III s. 460 2, s. 462 4: $2-6$, s. 463 5, s. 466 6: 1-4, Rk. I s. 238 6: 3 b, Me. III s. $1107: 10-15$, WE III s. $4678: 9-23$, Me. III s. 113 9: 1-6, s. 111 11:1-5, WE III s. 469 11: 1-16, s. 471 12, 19:18-25, Rk. I s. 238 25:1, 2 b-5, WE III s. 472 25, Rk. I s. 239 26: 1 b-21, Käs. III s. $4726: 19$, WE III s. 474 26, s. 476 29: $9-24$, s. $47830: 18-33$, Rk. I s. 334 33: $2-6,22-24$, Me. III s. 111 35 , WE III s. 48035 , Rk. I s. $17037: 16,17$ a, 20 , s. $70037: 16,17$ a, 20, WE III s. 482 38: $9-20$, Me. III s. $11240: 1-11$, WE III s. $48340: 1-17$, 28 b-31, s. 48542, Rk. I s. $33543: 24$ b-27, WE III s. $48843: 1-7,10$ $13,21-28$, s. $49044: 1-5,21-28$, Rk. I s. $33645: 18,21 \mathrm{~b}-25$, WE III s. $49245: 15-25$, s. 493 46:3-11, Me. III s. 130 49:1-7, s. 118 49: 8-26, WE III s. 494 49, s. 498 50:4-11, s. 499 51, Me. III s. 114 52: 1-10, 13-15, WE III s. 50252 : 1-10, Me. III s. 121 53, WE III s. 504 53, s. 506 54, Rk. I s. 337 55: 6-12, Me. III s. 122 55, WE III s. 508 55, s. 510 56, Käs. III s. $4757: 1-2$, WE III s. $51157: 1-2$, s. $51257: 12-21$, Me. III s. 11758 , WE III s. 573 58, Me. III s. $11560: 1-6$, WE III s. 515 60, Me. III s. 11461 : $1-3$, WE III s. 518 61, Me. III s. $11362: 1-5$, WE III s. 520 62, Rk. I s. 171 63: 15-19, WE III s. 521 63: 7-19, Rk. I s. 172 64, WE III s. 52364 , s. $52465: 13-25$, s. 52666.

Jer. Rk. I s. 118 1: 6 b-10, WE III s. 530 3: 6-25, Rk. I s. 137 3: 22 b-25, WE III s. 532 7: $3-28$, s. 535 8: $1-15$, s. 538 9: 23-24, Rk. I s. 340 10: $6-8$ a, $10: 23-25$ a, WE III s. 538 10: $23-25$, Rk. I s. 138 13: 15-27, s. 120 14: 7-9, 17 b-22, WE III s. 539 14: 13-22, s. 540 15: 15-21, Rk. I s. 142 16: 19-21, WE III s. $54216: 16-21$, Rk. I s. 174 17: $14,17,18$, WE III s. $54217: 5-27$, s. $54518: 1-12,18-23$, Rk. I s. 338 20: 7-13, WE III s. 548 20: 7 -18, s. 549 22: 13 - 17, s. 550 23: 1 -32, Käs. III s. 47 26: 19, Rk. I s. 142 31: $31-35$, s. 174 31: 18 b-19, WE III s. 554 31, Rk. I s. 243 32: 17-24, WE III s. 559 32: $37-41$, s. 560 33: $14-22$, s. $56144: 15-28$, s. $56345: 2-5$, s. 564 51: $15-19$.

Val.v. Rk. I si 175 3: 56-66, s. 176 5, WE III s. 565 1-5 (kokonaan).

Hes. WE III s. 578 13, s. 581 14: $13-23$, s. 583 18, s. 587 33: 1-9,

Rk. I s. 341 33: 11, WE III s. 588 34, Käs. III s. 47 37: 1-14.

Dan. WE III s. 594 2: 27-45 a, s. 597 7: 9—28 a, Rk. I s. 150 9: 4 b19, WE III s. $6009: 22$ b-27, s. 601 11: $36-45$, s. 602 12: 1-13.

Hoos. WE III s. 606 1-14 (kokonaan).

Jooel Rk. I s. 119 1:13-20, 2: 1—2 a, Me. III s. 116 2: 12-19, WE III s. 632 1-3 (kokonaan).

Aam. WE III s. 642 1-9 (kokonaan).

Ob. WE III s. 6621 (kokonaan). 
Joona Rk. I s. 179 2: 2-10, WE III s. 666 1-4 (kokonaan). Miika Rk. I s. 341 7: 18-20, WE III s. 673 1-7 (kokonaan). Naah. WE III s. $6871-3$ (kokonaan).

Hab. Rk. I s. 321 3: 2, 18-19, WE III s. 695 1-3 (kokonaan). Agricolalla on nykyisen Raamatun 2. luku jaettu siten, että jakeet 2:1-4 muodostavat 2. luvun ja jakeet 2: 5-20 3. luvun. Nykyinen 3. luku on lukuna 4.

Sef. WE III s. 704 1-3 (kokonaan).

Hagg. Proph. III s. 723 1-2 (kokonaan).

Sak. Proph. III s. 728 1: 1-6, $12-16$ a, 17 , s. 730 2, s. 732 3, s. 733 4: 1 - 7 , s. 734 5-8, s. 742 9: 7-17, s. 744 10-14.

Mal. Me. III s. 116 3: 1-4, Proph. III s. 759 1-4 (kokonaan).

\section{A pokryfikirjat 5}

Juudit Rk. I s. 162 9: 2-19 (nyk. Raam. 9: 2-14), s. 165 13: 7 b (nyk. Raam. 13:14 b), s. 235 16: 2-21 (nyk. Raam. 16:1-17).

Viis.k. Me. III s. 128 5: 1-5, Rk. I s. 314 9:1-6, 10—19 (nyk. Raam. 9: $1-6,10-18)$, s. 129 15: $1-3$.

Tob. Rk I s. 159 3:2-6, s. 233 13:1 b-10 (nyk. Raam. 13:1-7, tekstissä eroavuuksia).

Siir. Käs. III s. 48 7: 36 b, 39 (nyk. Raam. 7: 33 b, 36), s. 49 10:913 (nyk. Raam. 10: 9-11), Rk. I s. 316 23:1-6, s. 342 36:1-19, s. 317 51: 1-38 (nyk. Raam. 51:1-30).

Baar. Rk. I s. 144 2: 6-35, 3: 1-8 (nyk. Raam, 2. luku).

1 Makk. Rk. I s. $1804: 30$ b-33, s. 181 7:37-38, s. 182 7: 41-42.

2 Makk. Rk. I s. 182 1:24-29, s. 183 6: 30 b.

Lis. Est.k. Rk. I s. 165 1: 8 b-17 (nyk. Raam. 3: 2-10), s. 167 2:419 (nyk. Raam. 4: 3 b-19).

Lis. Dan.k. Rk. I s. 178 jak. 22-23, 42-43 (nyk. Raam. 22-23, 42).

Kolmen miehen kiitosv. Rk. I s. 224 jak. 52-91 (nyk. Raam. 29-65).

Man. ruk. Rk. I s. 160 jak. $1-15$.

s Tämä apokryfikirjoihin sisältyvien raamatunkohtien luettelo perustuu 1685:n Raamatun ja myös vanhan kirkkoraamattumme tekstiin ja jaejakoon. Sulkeissa on vastaava, edellisestä usein poikkeava nykyisen Raamattumme jaemerkintä. Eroavuus johtuu siitä, että apokryfikirjain uusi käännös perustuu kreikankieliseen alkutekstiin, kun taas vanhan käännöksen pohjana on Vulgatan latinankielinen teksti, ja nämä eroavat huomattavasti toisistaan. Jälkimmäinen sisälsi mm. monia kreikkalaisesta alkutekstistä puuttuvia lavennuksia, jotka uudesta käännöksestämme on jätetty pois. Lisäksi on jakeiden numerojärjestykseen tullut muitakin muutoksia (ks. Vanhan testamentin apokryfikirjat. Raamatunkäännöskomitean tekemä suomennos 1937 s. V). 


\section{Uusi testamentti}

Se Wsi Testamenti II s. 21-718.

Lisäksi muissa Agricolan teoksissa:

Matt. Rk. I s. 85 2:1-12, s. 88 5:1-12, Abck. I s. 011 6: 9-13, Rk. I s. $3298: 2$ b, 8 b, 25 b, s. 330 9: 27 b, 11: 25 b-26, 14: 30 b, 15: 22 b, 25 b, 27 b, Abck. I si. 015 16: 19, 18: 18, Käs. III s. 18 19: 5, 6, s. $2319: 3-6$, Pi. III s. 147 21: 4-5 a, s. 150 21: $10-17$ a, Rk. I s. $33126: 39$ b, 27:46 b, Abck. I s. 013 28: 18-20, Pi. III s. 189 28: 16, 17-18, 19 b-20 a, 20 b.

Mark. Rk. I s. 330 10: 47 b, Käs. III s. 9 10: 13-16, Pi. III s. 147 11: 5-7, s. 151 11:12-19, Rk. I s. 331 14:36, s. 87 16:14-20, Abck. I s. 013 16:15-16, Pi. III s. 189 16: 15, 16-18.

Luuk. Abck. I s. 012 1:28, 42 b, Rk. I s. 83 1:26-38, s. 244 1:4655, s. 246 1: $68-79,2: 14$, s. 247 2: 29-32, Abck. I s. 011 11: 2-4, Rk. I s. 331 18: 13 b, Pi. III s. 148 19: $39-44$, Rk. I s. 331 22: 42 , Pi. III s. 174 23: 6-11, Rk. I s. 332 23: 34 a, s. 331 23: 42 b, s. 332 23: 43 b, s. 333 23: 46 b, Käs. III s. 54 23: $39-43$.

Joh. Rk. I s. 81 1:1-14, Abck, I s. 013 3: 5-6, Rk. I s. 333 4: 15 c, Käs. III s. 49 5:25—29, s. 72 7:38-39, s. 59 8: 51 , s. 40 11:21-27, Rk. I s. 333 11: 41 b-42 a, Pi. III s. 148 12: $12-13$ a, 15 a, 16, 18, 19, s. $14912: 20-36$, s. $15012: 37-43$, s. $15112: 44-50$, s. $15914: 1-31$, s. $16115: 1-27$, s. $16316: 1-33$, s. $16517: 1-26$, Rk. I s. $32317: 1$ b26, s. 332 19: 26 b, 27 b, 28 b, 30 b, Abck. s. 015 20:22-23, Pi. III s. 187 20: 24-29, 21: 1-24.

Ap. t. Rk. I s. 333 1: 24 b-25, s. 322 4: 18 c, 24-30, s. 333 7:59 b, 60 b, s. 334 9: 6 a.

Room. Käs. III s. 49 8:10-11.

1 Kor. Abck. I s. 016 11: 23 b—25, Käs. III s. 37 11: 23 b—25, Pi. III s. 189 15: 6, Käs. III s. 49 15: 50-57.

1 Tim. Rk. I s. 248 1: 15-17.

Hebr. Rk. I s. 101 10: 19-25.

Ilm. Rk. I s. $2495: 9 \mathrm{~b}-10,11 \mathrm{~b}-13 \mathrm{a}$, s. $2505: 13 \mathrm{~b}, 7: 10 \mathrm{~b}-12$, $11: 16-18$, s. 251 15: 3 b-4.

Ennen kuin tämän luettelon perusteella saattoi ryhtyä laskemaan Agricolan suomentamien kohtien osuutta koko Raamatusta, oli otettava selville, mikä sivumäärä laskelmien pohjana olevassa 1685 :n Raamatussa oli varsinaista Raamatun tekstiä. Sillä vaikka tämä painos onkin, niin kuin aiemmin olen osoittanut, käsillä olevan tehtävän kannalta monessa suhteessa parempi kuin muut suomalaiset Raamatun painokset, niin sekin kuitenkin kaipasi tarkistusta. Tuosta 1572 sivun laajuisesta kirjasta oli karsittava kaikki, mikä ei ole varsinaista Raamatun tekstiä. Siitä oli helppo erottaa 
nimilehdet, omistukset, Vanhan testamentin esipuhe, rekisteri ja kirjain luettelo sekä Uuden testamentin rekisterit ja kaikki eri kirjain esipuheet, koska niillä on erillinen sivujen numerointi. Jäljelle jäi 1443 sivua, joihin sisältyi varsinainen Raamatun teksti, mutta samalla myös vielä sellaista, mikä ei siihen kuulunut, nimittäin koristeet, Vanhan testamentin eri kirjain esipuheet ja sisällysluettelot, Raamatun eri kirjain nimet ja niiden lopun merkinnät. Kun olin nämä kailkki mitannut, laskenut ja vähentänyt työn perustana olevan Raamatun viimeksi mainitusta sivumäärästä, kuoriutui esille käsittääkseni melko tarkasti varsinaisen Raamatun tekstin kokonaismäärä, joksi 1685 :n Raamatun sivuina laskettuna tuli 1405,5 sivua.

Tämän jälkeen mittasin millimetrimitalla luettelon perusteella jokaisen Agricolan kirjoihin sisältyvän Raamatun kohdan 1685 :n Raamatusta ja laskin, kuinka monta tämän kirjan sivua nuo Agricolan suomentamat kohdat vastasivat.

Vertaamalla tämän laskelman tuloksia 1685:n Raamatun eri osien pelkistettyihin sivumääriin laskin, kuinka suurta prosenttimäärää Agricolan kääntämien Raamatun paikkain luetteloon sisältyvät kohdat merkitsevät koko Raamatusta ja sen eri osista. Tulokset muodostuivat seuraaviksi.

Mikael Agricola on suomentanut ja julkaissut :

1. Vanhan testamentin kanonisista kirjoista . . . . . 21,7 \%

2. Apokryfikirjoista $\ldots \ldots \ldots \ldots \ldots \ldots \ldots \ldots \ldots \ldots, 6 \ldots \ldots$

3. Koko Vanhasta testamentista ............ 19,4\%

4. Uudesta testamentista ................ $100 \%$

5. Vanhan testamentin kanonisista kirjoista ja Uudesta

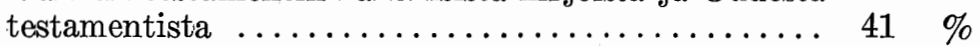

6. Koko Raamatusta .................. 36,9\%

Edellä olevat luvut osoittavat, että Agricola ei saanut Raamatun suomennostyötä lopulliseen päätökseen, vaikka se oli ollut hänen päämääränsä. Viimeisen, v. 1552 ilmestyneen teoksensa Ne Prophetat. Haggai. SacharJa. Maleachi. alkupuheessa hän lausuu:

Wiele Bibliast mwdh tulisit, ios nemet otoliset olisit.

Ostetaisin ia prucataisin, quin olis kylle mös coctolin. 
Hänen kirjansa eivät kuitenkaan näytä olleen "otolliset" silloiselle köyhälle ja valtaosaltaan lukutaidottomalle Suomen kansalle, eikä hänen työnsä saanut aikalaisilta tarpeellista ymmärtänıstä ja tukea. Agricolan muutamaa vuotta myöhemmin tapahtunut odottamaton kuolema katkaisi lopullisesti kaikki työn jatkamissuunnitelmat.

Mikael Agricolan työ on ollut suomalaisen Raamatun käännökselle perustavaa laatua, ja sillä on ollut arvaamaton merkitys ei ainoastaan kansamme hengellisen elämän viljelylle, vaan myös kirjakielemme ja yleensä suomalaisen sivistyselämän kehitykselle.

\section{Nrrlo Irola: Die von Michael Agricola übersetzten Bibelstellen und deren Anteil an der gesamten Bibel}

Über die von Michael Agricola ins Finnische übersetzten Bibelstellen gab es bisher nur ein Verzeichnis für das Alten Testament. Agricola hat bekanntlich das ganze Neue Testament übersetzt, Stellen daraus sind aber auch in seinen übrigen Werken vorhanden. Nur über die im Gebetbuch vorkommenden Zitate des Neuen Testaments gibt es vereinzelte Mitteilungen. Die bisherigen Angaben über Ayricolas Anteil an der gesamten Bibelübersetzung sind jedoch ungenau und teilweise widerspruchsvoll.

Der Verfasser hat Agricolas sämtliche Werke durchgearbeitet und auf Grund des dadurch gesammelten Materials ein Verzeichnis der darin vorkommenden von Agricola übersetzten Bibelstellen zusammengestellt. Angegeben werden darin u.a. das Werk und die Seite, wo die betreffende Stelle zu finden ist. Mit Hilfe dieses Verzeichnisses und der zweiten finnischen Bibelauflage von 1685 hat der Verf. jede übersetzte Stelle gemessen, die Ergebnisse dieser Messungen zusammengezählt und die so erhaltenen Summen mit der Anzahl der Seiten verglichen, die den eigentlichen Bibeltext enthalten. Daraus ergab sich Folgendes: Agricola hat übersetzt und herausgegeben 1. 21,7 \% der kanonischen Bücher des Alten Testaments, 2. $6 \%$ der apokryphen. Bücher, 3. 19,4 \% des gesamten Alten Testaments, 4. $100 \%$ des Neuen Testaments, 5. $41 \%$ der kanonischen Bücher des Alten Testaments und des Neuen Testaments, 6. 36,9\% der gesamten Bibel. 